\title{
Proses Pembuatan Dan Pemanfaatan Limbah Tulang Ikan Binggul Menjadi Kerupuk Tuibee Di Desa Daun Dusun Daun Barat Club Syebhen Star Sangkapura Pulau Bawean
}

\author{
M. Zainuddin F ${ }^{1}$, RN Rahmania ${ }^{2}$, Zakiyatul R ${ }^{3}$, M. Hamzah ${ }^{4}$, Ayu Fitriyah ${ }^{5}$ \\ ${ }^{1}$ Dosen Program Studi Teknik Industri, Universitas Muhammadiyah Gresik. \\ 2,3,4,5 Mahasiswa Program Studi Manajemen, Universitas Muhammadiyah Gresik. \\ Email: zainuddin@umg.ac.id, luchki.baskara@umg.ac.id
}

\begin{abstract}
ABSTRAK
Kerupuk tulang ikan binggul (Tuibee) merupakan produk diversifikasi dari pemanfaatan tulang ikan binggul sebagai bahan pembuatan kerupuk untuk memenuhi kebutuhan gizi masyarakat serta menunjukkanvariasi hasil olahan produk perikanan agar dapat meningkatkan nilai tambah pada komoditas ikan tersebut. Tujuan dari pelaksanaan Praktek Kerja Lapang (PKL) adalah untuk membuatkerupuk tulang ikan binggul (Tuibee), keadaan sanitasi dan higiene yang diterapkan dalam usaha pembuatan Kerupuk Tulang Ikan Binggul (Tuibee), mengetahui komposisi gizi dan manfaat dari kerupuk tulang ikan binggul, dan mengetahui aspek finansial dari usaha pembuatan kerupuk tulang lele di Dusun Daun Barat Syebhen Star. Metode pengambilan data yang dilakukan yaitu dengan metode deskriptif sedangkan teknik pengambilan datanya dilakukan dengan cara observasi, wawancara, partisipasi aktif dan dokumentasi. Alur proses pembuatan kerupuk tulang ikan binggul (Tuibee) meliputi persiapan bahan baku, persiapan bahan tambahan, pembuatan bubur tulang lele, pencampuran adonan, pencetakan, pemotongan, penjemuran, pengemasan, dan pelabelan. Demi menghasilkan produk yang berkualitas dan aman untuk dikonsumsi, Desa Daun Syebhen Starmenerapkan ilmu yang diberikan oleh beweone dalam proses pembuatan tulang ikan binggul (Tuibee) dengan memasarkan ke masyarakat luas dan menjadikannya penghasilan tambahan dalam dunia pemasaran.
\end{abstract}

Kata Kunci: Ikan binggul, proses pembuatan kerupuk, kerupuk tulang ikan binggul. 


\section{DedikasiMU (Journal of Community Service)}

Volume 1, Nomor 1, Desember 2019

\section{PENDAHULUAN}

Ikan binggul termasuk salah satu jenis ikan air tawar yang memiliki rasa daging enak dan gurih. Tekstur dagingnya lembut dan empuk. Hal ini membuat ikan binggul memiliki banyak penggemar. Selain cita rasa yang enak dan gurih, binggul ternyata mempunyai kandungan gizi yang tinggi. Binggul memiliki kandungan gizi yang cukup tinggi.Konsumsi masyarakat yang begitu besar terhadap olahan ikan binggul, menyebabkan peningkatan limbah sisa pengolahan ikan binggul. Pemanfaatan limbah dari hasil perikanan, seperti kepala, tulang, sisik dan kulit kebanyakan masih kurang dimanfaatkan dan menjadi limbah pada industri pengolahan di bidang perikanan. Tulang ikan merupakan salah satu limbah dari industri perikanan yang belum dimanfaatkan dengan baik. Tulang ikan terdiri dari senyawa organik dan senyawa anorganik (mineral) (Ramdanyet al., 2014).

Salah satu alternatif solusi untuk memanfaatkan limbah tulang ikan adalah dalam bentuk produk kerupuk. Prospek pemanfaatan dalam bentuk kerupuk dari tulang ikan ini bisa memberikan solusi, mengingat pembuatan kerupuk relatif mudah dan murah. Selain itu kerupuk juga digemari oleh hampir semua lapisan masyarakat, karena mempunyai rasa yang khas. Kerupuk merupakan salah satu produk pangan yang berasal dari Indonesia, terbuat dari tepung tapioka, dicampur dengan bahan tambahan makanan dan dilakukan penggorengan menggunakan minyak sebelum disajikan. Kadar air kerupuk berkisar antara 10,3\%sampai 11,3\%. industri kerupuk baik di Kota maupun di Desa (Sukendaret al., 2013). Pemanfaatan tulang binggul untuk pembuatan kerupuk merupakan bentuk diversifikasi produk dengan memanfaatkan limbah tulang ikan sebagai bahan baku pembuatan kerupuk. Tulang juga merupakan sumber mineral penting: natrium, fosfor, dan kalsium. Di antara mereka, kalsium ion $(\mathrm{Ca} 2+)$ penting untuk perkembangan tulang manusia dan gigi terutama pada bayi. Pemanfaatan tulang ikan bisa menjadi sumber alami $\mathrm{Ca} 2+$ untuk menjadi bahan makanan dan $\mathrm{Ca} 2+$ tambahan. Ini akan menjadi strategi untuk memanfaatkan secara maksimal sumber daya ikan serta untuk secara efektif mengurangi limbah dari industri perikanan (Hemung, 2013).

Oleh sebab itu, Praktek Kerja Lapangan ini bertujuan untuk mengolah dan memproses tulang ikan binggul dan kandungan gizi serta manfaat kerupuk tulang ikan 


\section{DedikasiMU (Journal of Community Service)}

Volume 1, Nomor 1, Desember 2019

binggul ( Clarias sp.) di DesaDaun Dusun Daun Barat Syebhen Star Sangkapura Bawean, Gresik jawa Timur.

\section{METODE PELAKSANAAN}

Praktek Kerja Lapangan ini dilaksanakan pada tanggal 22 Juli sampai 30Agustus 2019 di Desa Daun Dusun Daun Barat Syebhen Star Sangkapura Bawean, Gresik jawa Timur. Metode yang digunakan pada pelaksanaan Praktek Kerja Lapangan ini adalah metode deskriptif. Metode Deskriptif Analisis yaitu metode penelitian yang digunakan dalam pengumpulan data dengan meneliti masalah-masalah yang sedang terjadi pada saat ini, kemudian data tersebut dikumpulkan dan disusun, setelah itu diolah dan dianalisis (Sugiyono, 2003).

Dalam pelaksanaan PKL ini kegiatan yang dilakukan meliputi observasi, wawancara, partisipasi aktif serta dokumentasi. Teknik oberservasi yaitu cara pengumpulan data dengan jalan pengamatan langsung secara cermat dan sistematik baik secara partisipatif maupun non partisipatif (Sianiparet al., 2009). Dalam Praktek Kerja Lapangan, observasi tersebut dilakukan terhadap metode yang digunakan dalam proses pembuatan kerupuk tulang ikan binggul (Tuibee) mulai dari awal proses sampai akhir proses serta aspek sanitasi dan hygiene. Teknik wawancara yaitu cara pengumpulan data dengan bertanya langsung atau berdialog dengan narasumber. Proses wawancara dilakukan dengan menggunakan alat pengumpulan data berupa daftar pertanyaan (kuesioner) terstruktur, hal ini bertujuan untuk mendapatkan informasi yang terarah dan sesuai (Soeratno dan Arsyad, 1999). Hal-hal yang ditanyakan dalam proses wawancara meliputi sejarah berdirinyaclub Syebhen Star, struktur organisasiClub Syebhen Star,ketenagakerjaan, penggunaan modal, biaya produksi, produksi, pemasaran hasil, manajemen, permasalahan yang dihadapi dan faktor-faktor yang mempengaruhi usaha serta segala sesuatu yang berhubungan dengan proses pembuatan kerupuk tulang ikan binggul (Tuibee). Biasanya, diajukan suatu tanya jawab langsung yang tersusun dalam suatu daftar pertanyaan atau quisioner. Metode partisipasi aktif merupakan teknik pengumpulan data dengan cara ikut serta atau melibatkan diri dalam keseluruhan kegiatan secara langsung dalam suatu aliran proses di suatu unit produksi. Dalam praktek kerja lapang ini untuk memberikan informasi kepada masyarakat Syebhen Star bahwa manfaat limbah tulang ikan sangat bermanfaat sekali untuk kesehatan. 


\section{DedikasiMU (Journal of Community Service)}

Volume 1, Nomor 1, Desember 2019

Dengan mengadakan workshop dan pelatihan kepada masyarakat Syebhen Star dan mengikuti secara langsung kegiatan proses kegiatan partisipasi aktif ini diikuti mulai dari persiapan bahan baku, pelaksanaan pembuatan kerupuk tulang ikan binggul (Tuibee), hingga sampai produk siap untuk dipasarkan. Teknik Dokumentasi yaitu teknik pengumpulan data dengan cara mencatat peristiwa-peristiwa yang sudah berlalu. Seperti berbentuk tulisan, gambar. Kegiatan dokumentasi pada Praktek Kerja Lapangan ini terutama meliputi proses pengolahan bahan baku hingga menjadi produk kerupuk tulang ikan binggul yang siap dipasarkan. Selain pengambilan data primer (observasi, wawancara, partisipasi aktif serta dokumentasi), juga dilakukan pengambilan data sekunder. Dalam Praktek Kerja Lapang ini data sekunder diperoleh dari laporanlaporan, pustaka-pustaka serta data yang diperoleh dari observasi. Untuk data internal merupakan data yang diperoleh dari dalam lokasi Praktek Kerja Lapang yaitu di Desa Daun Dusun Daun Barat Syebhen Star Sangkapura Bawean, Gresik jawa Timur. Sedangkan data eksternal merupakan data yang diperoleh dari pihak luar baik dari lembaga pemerintah, lembaga swasta serta masyarakat yang terkait dalam usaha pembuatan kerupuk tulang ikan binggul (Tuibee)

\section{HASIL DAN PEMBAHASAN}

\section{A. Keadaan Umum Lokasi Usaha}

Dusun Daun Baratmerupakankelompok pengolahan dan pemasaran yang bergerak di bidang pengolahan ikan binggul. Letak geografisnya dekat dari perairan, sehingga dalam proses pembuatan tidak membutuhkan usaha yang besar dalam hal distribusi ikan binggul.

Lokasi yang digunakan untuk tempatpengolahan produk olahan ikan binggul terletak dirumah Bu Lily, pemilihan lokasi ini karenadekat dengan jalan raya sehingga memudahkansaat akses transportasi dalam mengambil bahanbaku dan pemasaran. Lokasi ini merupakantempat untuk produksi sekaligus tempat pemasaran. Jarak rumah $\mathrm{Bu}$ Lily denganlokasi pembelian bahan baku sangatlah dekat sekitar $1 \mathrm{~km}$ sebab di dusun Daun Barat banyakpenduduknya yang memiliki keramba binggul untukbudidaya, sehingga mudah untuk mendapatkanbahan baku. 


\section{DedikasiMU (Journal of Community Service)}

Volume 1, Nomor 1, Desember 2019

\section{B. Struktur Organisasi}

Club Syebhen Star diketuahi oleh Bapak Suhud dan di bina langsung oleh remaja di wilayah Syebhen Star, dengan ibu Lily sebagai coordinator wanita atau kaum putri di wilayah Syebhen Star. Sebenarnya Dusun Daun Barat memiliki 4 dusun:

1. Syebhen Star

2. Asam Jaya

3. $\mathrm{BBC}$

4. Mutiara

Namun kelompok KKN kita diperintahkan untuk fokus kepada Club Syebhen Star mengingat tempat tinggal kelompok kami masih dalam wilayah Syebhen Star.

Pembuatan kerupuk tulang ikan ini adalah temuan dari teman-teman KKN prodi Manajemen yang melihat banyaknya limbah tulang ikan binggul yang tidak dimanfaatkan lagi atau dibuang, dengan bermodalkan ide dan mencoba akhirnya kami berhasil membuat produk baru yang bisa dikembangkan oleh ibu-ibu di wilayah Syebhen Star untuk lading usaha baru.

Pembuatan kerupuk tulang ikan binggul di ketuahi oleh Ibu Lily sebagai coordinator dan mengarahkan jalannya pembuatan kerupuk tlang ikan binggul dengan sangat baik sekali, ada sekitar $20 \mathrm{ibu}$-ibu yang hadir dalam pembuatan dan 7 mahasiswa KKN prodi manajemen sebagai pengarah dan memberikan informasi mengenai manfaat limbah tulang ikan binggul yang sangat banyak sekali, selain itu ada pula 8 orangtenaga kerja dimana 3 orang sebagai pengurusyang bertugas dalam pemasaran produk dan 6orang lainnya berperan sebagai anggota yangbertugas dalam proses produksi.

Pembuatan kerupuk dari limbah tulang ikan binggul (Tuibee) ini merupakan pekerjaan sampingan untuk pemberdayaan ibu-ibu rumah tangga di daerah sekitar.Dalam 1 kali produksi dapat menghasilkan \pm 30 kemasan.Namun proses produksi juga tergantung padapesanan, jika banyak pesanan atau ada pameranjumlah produksi dapat bertambah tergantungorderan. 


\section{DedikasiMU (Journal of Community Service)}

Volume 1, Nomor 1, Desember 2019

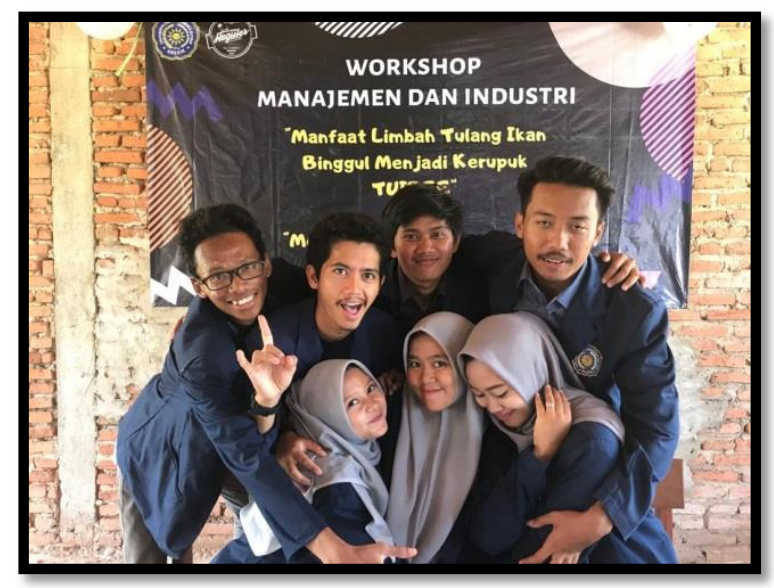

Gambar 1. Kelompok Prodi Manajemen

\section{Proses Produksi}

\section{- Persiapan Bahan}

Proses pembuatan kerupuk tulang ikan meliputi tahapan persiapan bahan baku danbahan tambahan, pembuatan bubur tulang ikan binggul,pencampuran adonan, pencetakan, pemotongan,penjemuran, pengemasan, dan pelabelan.Bahan baku yang digunakan dalampembuatan kerupuk tulang ikan binggul adalah ikan binggul yang berukuran $7-12 \mathrm{~cm}$. Sehingga dapatdimanfaatkan menjadi suatu produk dengan nilaiekonomis yang tinggi. Untuk sekali produksibiasanya membutuhkan $1 \mathrm{~kg}$ ikan binggul.Pemanfaatan tulang binggul untuk pembuatankerupuk merupakan bentuk diversifikasi produkdengan memanfaatkan limbah tulang ikan sebagai bahan baku pembuatan kerupuk.

Tulangjuga merupakan sumber mineral penting:natrium, fosfor, dan kalsium. Pemanfaatan tulangikan bisa menjadi sumber alami Ca2+untukmenjadi bahan makanan dan $\mathrm{Ca} 2+$ tambahan.Mengkonsumsi kalsium secara teratur dianggapsebagai faktor paling penting bagi kesehatantulang. Selain kalsium dan fosfor prosespembentukan tulang juga dipengaruhi olehkalsitriol $(1,25-(\mathrm{OH})$

Osteoporosis adalah keadaan kurangnyamasa tulang per unit volume dan mikroarsitekturjaringan tulang yang buruk namun bukandisebabkan oleh defek mineralisasi(osteomalasia).Osteoporosis menyebabkan tulangmenjadi lebih rapuh sehingga risiko frakturmeningkat baik pada masa kanak maupun kelakdi usia dewasa sehinggaosteoporosis dikenal sebagaipenyakit pediatri dengan konsekuensi geriatric karena 90\% masa tulang terbentuk sebelum usia20 tahun. Kalsium adalah kation 


\section{DedikasiMU (Journal of Community Service)}

Volume 1, Nomor 1, Desember 2019

ekstrasel utama.Peran utama kalsium adalah untuk kontraksi daneksitasi otot jantung dan otot lainnya, transmisisinap sistem saraf, agregasi platelet, koagulasi,dan sekresi hormon dan regulator lain yangmemerlukan eksositosis (Setyoriniet al ,2009).

Tulang ikan sangat kaya akan kalsium yang dibutuhkan manusia. Kalsium diketahui menjadi elemen sangat penting yang diperlukan untuk berbagai fungsi di dalam tubuh kita termasuk penguatan gigi dan tulang, fungsi saraf dan banyak reaksi enzimatik yang membutuhkan kalsium sebagai kofaktor.

Selain itu bahan tambahan yangdigunakan ada tepung terigu, tepung beras,tepung tapioka, garam, telur, bawang putih, penyedap rasa, dan air.

Tabel 1. Formula kerupuk tulang ikan binggul per $1 \mathrm{~kg}$ bahan

\begin{tabular}{|l|l|l|}
\hline No. & Jenis Bahan & Jumlah \\
\hline 1. & Ikan binggul (g) & 1000 \\
\hline 2. & Tepung terigu (g) & 500 \\
\hline 3. & Tepung tapioca (g) & 400 \\
\hline 4. & Garam (g) & 20 \\
\hline 5. & Bawang Putih (g) & 100 \\
\hline 6. & Bubuk Kaldu (g) & 30 \\
\hline 7. & Bubuk Kemiri (g) & 10 \\
\hline
\end{tabular}

\section{- Pembuatan Tulang Ikan Binggul}

Dalam pembuatan bubur ikan binggul yangpertama dilakukan adalah ikan binggul disiangi, dibuang insang dan jeroannya lalu dicuci hinggabersih.Kemudian dipisahkan daging dari tulangikan dan direbus tulang dalam panci selama 30menit. Tujuan dari perebusan ikan binggul ini adalah untuk melunakkan tulang ikan dan untuk mengkoagulasi protein. Setelah direbus, dihasilkan tulang binggul yang lebih lunak dan kaldu dari perebusan disimpan untuk proses pencampuran dengan bahan tambahan. Kemudian tulang binggul dipresto selama 30 menituntuk lebih melunakkan tulang/duri ikan binggul. Pada saat penghaluskan dengan cara diblender,ditambahkan pula bawang putih sebagai bumbudan penambah cita rasa pada kerupuk tulang binggul. 


\section{DedikasiMU (Journal of Community Service)}

Volume 1, Nomor 1, Desember 2019

\section{- Pencampuran Adonan}

Setelah tulang ikan binggul dan bawang putihdihaluskan, kemudian dilakukan proses pencampuran bahan tambahan di dalam baskom.

Adonan bubur tulang binggul ditambahkan dengantepung terigu, tepung tapioka, telur, garam dan penyedap rasa. Tujuan ditambahkan tepung terigu, tepung beras dan tepung tapioka yaitu supaya adonan lebih kenyaldan berisi. Lalu ditambahkan air kaldu perebusan tulang ikan binggul agar rasa dari ikan binggul dapat lebihterasa kuat, penambahan kaldu dilakukan secarabertahap hingga adonan kental dan tidak terlaluencer.

Proses pencampuran ini dilakukan secara manual menggunakan tangan agar dapat merasakan adakah duri yang tercampur pada adonan.

setelah adonan agak kental barudigunakan centong saat proses pengadukan. Setelah selesai dilakukan pencampuran, adonandisaring dan diletakkan pada baskom untukmemastikan bahwa tidak ada duri yang masihutuh tertinggal pada adonan. Tujuan dari homogenisasi adalah untuk memperluas permukaan adonan sehingga mempersingkat waktu gelatinisasi, dan memudahkan prosespencetakan.

Gelatinisasi pati merupakan istilah yangdigunakan untuk menerangkan serangkaian kejadian tidak dapat kembali (irreversible) yangterjadi pada pati saat dipanaskan dalam systemair. Struktur semikristal granula pati bersifat tidaklarut dalam air dingin. Apabila granula patidisuspensikan dalam air maka pati berangsur-angsur akan mengendap. Namun, granula patiakan mengembang dalam air panas setelahmelewati suhu tertentu. Proses pengembangangranula pati tersebut bersifat bolak-balik (reversible) apabila tidak melewati suhu gelatinisasidan akan menjadi tidak bolak-balik ( irreversible) apabila telah mencapai suhu gelatinisasi(Kusnandar, 2010). 


\section{DedikasiMU (Journal of Community Service)}

Volume 1, Nomor 1, Desember 2019

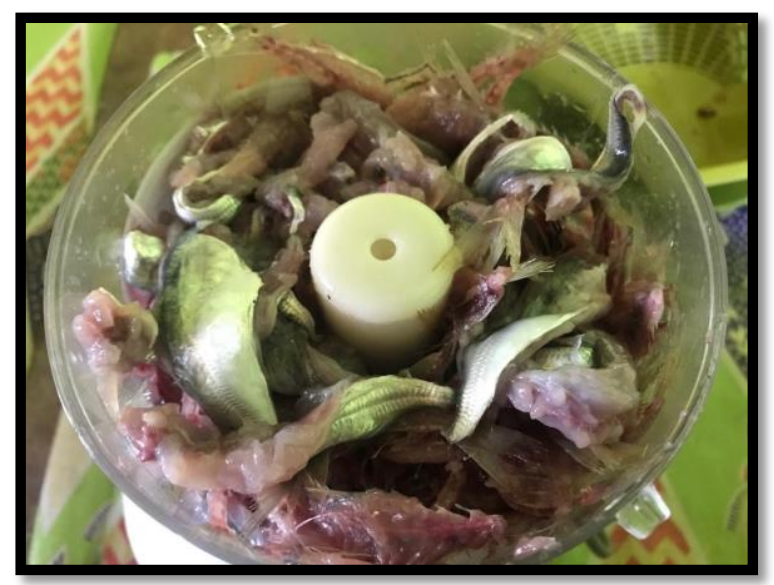

Gambar 2. Pencampuran adonan

\section{- Pencetakan}

Adonan dituangkan pada wadah cetakanberbentuk bulat untuk memudahkan saat proses pencetakan dengan teflon. Saat prosespencetakan bagian belakang teflon yang digunakan karena dirasa lebih mudah saat mencetak adonan dengan didapatkan hasil lebar dan tebal yang sama tiap cetakannya. Saat pencetakan adonan di teflon jangan ditekanterlalu keras, cukup hingga semua luaspermukaan teflon dilumuri oleh adonan, sehingga diperoleh lebar dan tebal adonankerupuk yang sama. Kemudian dipanaskan hingga semua permukaan adonan kering dantidak basah lagi. Ketika adonan dipanaskan tidak memerlukan waktu yang lama dan akan cepat kering karena panas merata dari pinggir hingga akhirnya ke tengah adonan yang menyebabkan adonan tidak lengket dan terjatuh dengan sendirinya saat teflon dibalik untuk mengangkat adonan. Langkah ini dilakukan secara terus menerus hingga adonan habis.

\section{- Pemotongan}

Setelah adonan kerupuk yang sudahdicetak dingin, dilakukan proses pemotongansecara manual menggunakan pisau. Karenabentuk awal adonan bulat maka dipotong menjadi 8 bagian sehingga berbentuk segitiga.Pemotongan adonan menggunakan pisau yangtajam.Selain itu pada kedua permukaan pisaudiolesi dengan minyak goreng terlebih dahuluagar pisau tidak lengket pada adonan dan hasil pemotongan juga terlihat lebih rapi. 


\section{DedikasiMU (Journal of Community Service)}

Volume 1, Nomor 1, Desember 2019

\section{- Penjemuran}

Setelah adonan dipotong, disusun diataspara-para untuk dijemur.Penjemuran inibertujuan untuk mengeringkan kerupuk tulanglele dengan mengurangi kandungan airnya, dandilakukan secara langsung di bawah sinarmatahari di halaman belakang rumah.

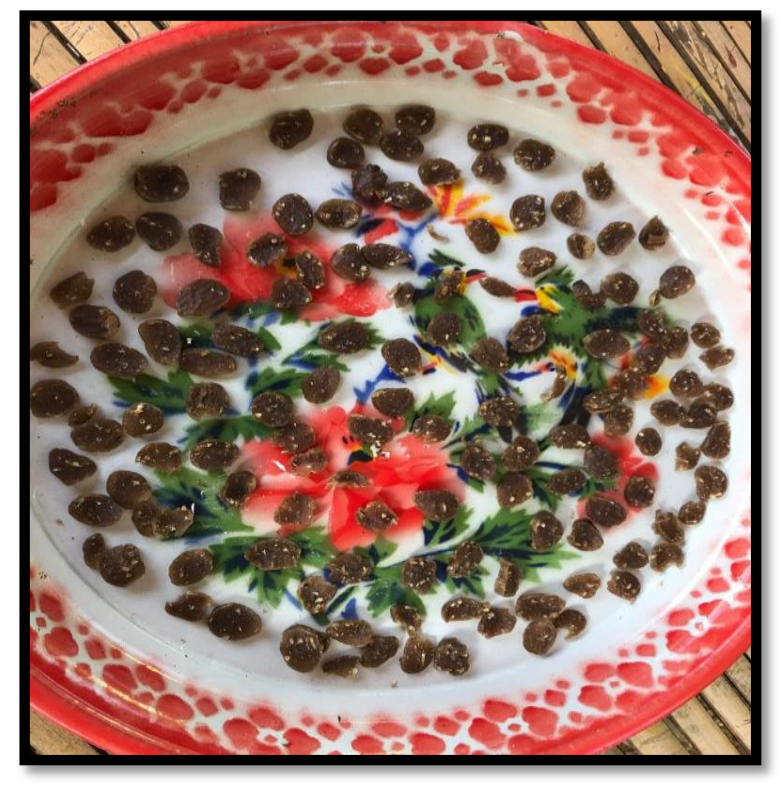

Gambar 3. Penjemuran adonan

Lama waktu penjemuran dengan sinar matahari tidakdapat ditentukan karena tergantung pada cuacadan banyaknya intensitas sinar matahari. Biasanya kerupuk tulang binggul paling cepat kering setelahdijemur selama \pm 1 sampai 2 hari jika cuacabenarbenar panas. Karena penjemuran dilakukan di tempat yang terbuka maka kebersihannya sukar untuk diawasi sehingga ada kemungkinan terjadinya kontaminasi dengan debu dan udara luar.

\section{- Pengemasan}

Setelah kerupuk tulang binggul kering dan memiliki tekstur yang kaku lalu diangkat dan dibiarkan hingga dingin beberapa saat. Kemudian dilakukan pengemasan dengan menggunakan plastik PP 0,1 x $20 \mathrm{~cm}$. digunakan plastik jenis PP karena plastiknya lebih tebal, lebih kuat, tahan terhadap suhu tinggi sehingga cocok untuk digunakan sebagai bahan pengemas. Setelah kerupuk dimasukkan kedalam plastik kemudian sebanyak 100. Pengemasan bertujuan untuk menghindari kontaminasi 


\section{DedikasiMU (Journal of Community Service)}

Volume 1, Nomor 1, Desember 2019

mikroorganisme, terutama kontaminasi mikroba patogen dan catatfisik saat didistribusikan ke konsumen.

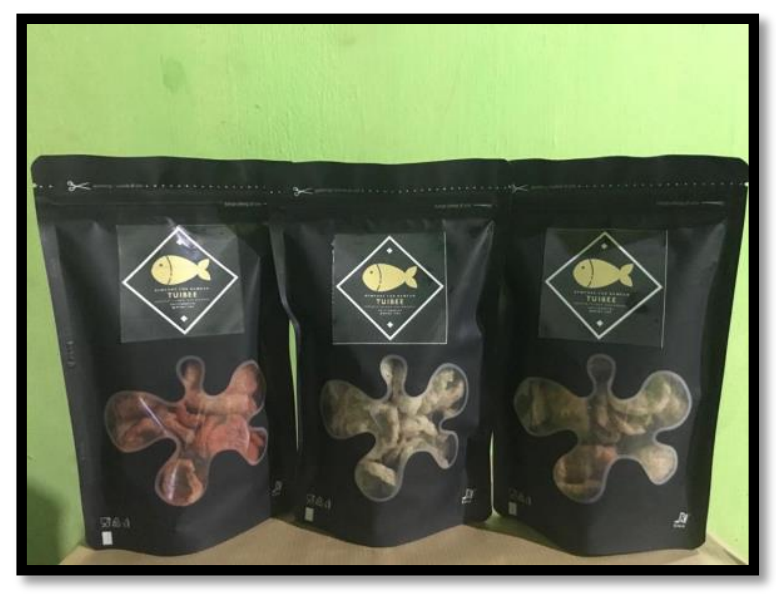

Gambar 4. Pengemasan

\section{- Pelabelan}

Setelah disealer dilakukan pelabelan padaproduk, pelabelan bertujuan untukmemberitahukan identitas produk padakonsumen.Setiap produk memiliki identitasmasing-masing yang merupakan ciri khas dariproduk tersebut. Dalam label berisi namaproduk, perusahaan yang memproduksi, alamattempat produksi, komposisi, tanggal kadaluarsa,dan nomor produksi. Proses pelabelan dilakukandengan cara pemberian stiker. Setelah pelabelanselesai, produk kerupuk tulang lele disimpan dietalase untu dipasarkan.

\section{Sanitasi dan Hygiene}

\section{- Sanitasi dan Hygiene Bahan Baku}

Bahan baku utama dalam pembuatan kerupuk tulang binggul adalah ikan binggul yang diperoleh langsung. Bahan baku pembuatan kerupuk tulang binggul ini didapatkandalam keadaan segar. Hal ini karena pengambilanbahan baku langsung berasal dari laut yang berada dekat dengan usaha sehingga secaraorganoleptik bahan baku yang didapatkan dalam kondisi yang baik. Setelah ikan ditangkaplangsung dicuci dan disiangi untuk segera diproses agar mutunya tetap terjaga. Hadiwiyoto(1993) mengatakan bahwa proses pencucian bertujuan untuk menghilangkan semua jenis 


\section{DedikasiMU (Journal of Community Service)}

Volume 1, Nomor 1, Desember 2019

kotoran seperti darah, lendir maupun lumpur. Selain itu air bersih dapat mengurangi jumlah bakteri yang ada.

\section{- Sanitasi dan Hygiene Bahan Tambahan}

Bahan tambahan yang digunakan adalahtelur, bawang putih, garam dapur, penyedaprasa/ MSG yang disimpan di dalam wadah pada tempat yang kering sehingga kelembabannya terjaga dan mutu bahan tersebut dapat dipertahankan lebih lama. Sanitasi bahan tambahan dalam suatu bahan pangan sangat berpengaruh terhadap tingkat kualitas suatu produk. Penambahan bahan tambahan sangat menentukan kualitas suatu bahan pangan yaitu apakah semakin tinggi atau semakin menurun.

\section{- Sanitasi dan Hygiene Peralatan}

Peralatan yang digunakan dalam proses pembuatan kerupuk tulang binggul sudah memenuhipersyaratan sanitasi dan hygiene. Semua alat yangdigunakan mulai dari alat-alat dapur yang terbuat dari plastik sampai yang terbuat dari logam sebelum dan setelah digunakan dicuci bersih dengan menggunakan air bersih dan sabun pembersih. Kemudian disimpan ditempat yang bersih. Saat mengolah makanan, erat kaitannya dengan sanitasi yaitu adanya kontaminasi silang( crosscontamination ). Kontaminasisilang adalah tertularnya bakteri dari satu makanan atau peralatan atau meja kerja ke makanan lain. Untuk menghindari hal tersebut maka sanitasi pada peralatan kerja dapur yang berada di areap engolahan harus terjaga dengan benar (Indira,2010).

\section{- Sanitasi dan Hygiene Air}

Air dalam pengolahan makanan perlumendapat perhatian khusus karena berperanbesar dalam semua tahapan produksi. Pada tahappersiapan, air digunakan untuk mencuci bahanbaku dan bahan tambahan. air digunakan untukproses pemasakan yaitu untuk merebus ikan leledan mencuci peralatan yang digunakan.

\section{- Sanitasi dan Hygiene Pekerja}

Para pekerja yang membuat kerupuk tulang binggul tidakmenggunakan perlengkapan khusus yangberfungsi untuk menjaga dari kontaminasi silang,karena masih berskala home industry. Pada saatproses pencampuran bahan pun pengadukannya 


\section{DedikasiMU (Journal of Community Service)}

Volume 1, Nomor 1, Desember 2019

dilakukan dengan menggunakan tangan tanpa memakai sarung tangan. Tetapi pekerja tetap mencuci tangannya terlebih dahulu sebelum proses pengadukan. Para pekerja juga tidak memakai celemek saat proses produksi, sehingga produk masih mungkin terkontaminasi oleh parapekerja.

\section{- Saitasi dan Hygiene Pengolahan danLingkungan}

Lingkungan tempat pengolahan kerupuk tulang binggul ini berada satu unit dengan rumah tempat tinggal Ibu Lily. Tempat pengolahan inicukup layak untuk menjadi tempat produksi makanan karena pengaturan lokasinya sekaligus sebagai dapur sehingga memudahkan pekerja dalam melakukan proses pembuatan produk dan menyimpan peralatan produksi yang. Sanitasi dan hygiene di luar ruang produksi juga sudah cukup bagus. Dibagian belakang luar rumah terdapat saluran pembuangan air yang berupa selokan. Kondisi di dalam maupun di luar unit usaha umumnya bersih karena digunakan juga sebagai tempat tinggal yang dibersihkan setiap hari.

\section{- Sanitasi dan Hygiene Produk Akhir}

Pada produk akhir pembuatan kerupuk tulang ikan binggul, sanitasi dan hygiene produk sudah cukup baik. Hal tersebut dibuktikan dengan adanya perlakuan akhir produksi yaitu dengan pengemasan kedap udara.

Hasil olahan kerupuk tulang binggul dikemas dalam wadah plastik untuk menghindari kontak udara yang dapat menyebabkan reaksi oksidasi (ketengikan) yang akan mempengarui citarasa kerupuk. Pengemasan kerupuk tulang ikan binggul ini cukupbaik, karena plastik yang digunakan sesuai dengan sifat produk penyimpanannya tahan terhadap suhu tinggi.

\section{- Penanganan Limbah}

Limbah dari hasil pengolahan kerupuk tulang lele ini berupa limbah padat dan limbah cair. Limbah cair berupa air bekas pencucian ikan binggul dan air hasil pencucian alat-alat produksi yang langsung dialirkan melalui selokan kecil yang berhubungan dengan saluran air yang lebih besar. Keadaan selokan dan saluran air ini tidak kotor dan tidak bau karena saluran air lancar. Sedangkan limbah padat berupa jeroan ikan binggul, sisa kupasan bawang putih, bungkus penyedap rasa dan tepung, 


\section{DedikasiMU (Journal of Community Service)}

Volume 1, Nomor 1, Desember 2019

serta cangkang telur yang langsung dibuang ke tempat sampah. Pada tempat sampah juga memakai kantong plastik yang digunakan untuk membungkus sampah, sehingga kebersihannya tetap terjaga.

\section{- Kandungan Gizi Kerupuk Tulang Lele}

Analisis proksimat bertujuan untukmenentukan komposisi kimia utama dari bahanbaku dan produk, yaitu ikan binggul dan kerupuk tulang binggul. Parameter analisis kerupuk tulang binggul adalah kadar protein, lemak, air, abu dankarbohidrat. Analisis proksimat ini dilakukan diLaboratorium Pengujian Mutu dan KeamanananPangan, Fakultas Teknologi Pertanian,Universitas Brawijaya Malang.

\section{E. Analisa Usaha}

\section{- Permodalan}

Pada Dusun Syebhen Star digunakan untuk pembuatan kerupuk tulang binggul meliputi modal tetap dan modal kerja.Modaltetap atau yang bisa dikatakan investasi yangdigunakan pada pengolahan kerupuk tulang binggul sebesar Rp 400.000. Sedangkan untuk modalkerja merupakan modal yang besarnya berubah-ubah sesuai dengan produk yang dipasarkan ataubisa disebut dengan biaya produksi, modal kerjayang digunakan sebesar Rp 500.000 per bulan.

\section{- Biaya Produksi}

Biaya produksi mencakup dua macamyaitu biaya tetap dan biaya variable. Biaya tetap(fixed cost) adalah biaya yang penggunaannyatidak habis dalam satu masa produksi, misalnyabibit, bambu, tali, plastik, pisau dan lain-lain, sedangkan biaya variabel adalah biaya yang penggunaannya habis atau dianggap habis dalam satu masa produksi, misalnya tenaga kerja (Tutupary, 2013). Biaya tetap (Fixed cost) pada pengolahan kerupuk tulang binggul ini sebesar Rp139.200,00. Sedangkan biaya tidak tetap sebesar Rp 104.400,00 per bulan.

\section{- Keuntungan}

Keuntungan usaha akan diperoleh jikatotal penerimaan lebih besar daripada total biayapengeluaran. Dimana pendapatan usahamerupakan selisih antara penerimaan dan 


\section{DedikasiMU (Journal of Community Service)}

Volume 1, Nomor 1, Desember 2019

total biaya pengeluaran. Total biaya pembuatan kerupuk tulang binggul di Dusun Daun Barat Syebhen Star per bulan sebesar Rp. 243.600,00. Sedangkan jumlah total hasil usaha per bulan Rp.500.000,00. Sehingga keuntungan bersih prosespembuatan kerupuk tulang lele per bulan sebesar Rp. 256.400,00.

\section{- R/C Ratio}

Tingkat pendapatan usaha dapat diukur menggunakan analisis penerimaan dan biaya ( $\mathrm{R} / \mathrm{C}$ ratio analisis) yang didasarkan pada perhitungan finansial. Analisis ini menunjukkan besar penerimaan usaha yang akan diperoleh pengusaha untuk setiap rupiah biaya yang akan dikeluarkan untuk kegiatan usaha. Pada usaha pembuatan kerupuk tulang binggul $\mathrm{R} / \mathrm{C}$ rationya sebesar 2,05 rupiah. Jadi usaha ini dapat dikategorikan memberikan keuntungan karenamempunyai nilai $\mathrm{R} / \mathrm{C}$ ratio lebih dari 1.

\section{- Analisa Break Even Point (BEP)}

Dalam perhitungan menggunakan analisaBEP diperoleh hasil bahwa produk BEPberdasarkan unit sebesar 36 bungkus yangartinya, usaha pembuatan kerupuk tulang binggul initidak rugi dan tidak untung (impas) saat produklaku sebanyak 36 bungkus dalam tiap bulannyadan berdasarkan sales sebesar Rp 175.935,00yang artinya, usaha pembuatan kerupuk tulang ikan binggul ini tidak rugi dan tidak untung (impas) saatdihasilkan pendapatan sebesar Rp 175.935,00dari penjualan dalam tiap bulannya.

\section{KESIMPULAN DAN SARAN}

\section{A. Kesimpulan}

Kesimpulan yang dapat diambil dari hasil Praktek Kerja Lapang di Dusun Daun Barat Syebhen Star adalah:

Tahapan pada proses pembuatan kerupuk tulang binggul adalah persiapan bahan baku, persiapan bahan tambahan, pembuatan bubur ikan binggul, pencampuran adonan, pencetakan, pemotongan, penjemuran, pengemasan, dan pelabelan.

\section{B. Saran}

Saran untuk Dusun Daun Barat Syebhen Staryaitu agar selalu memperhatikan kondisisanitasi danhygiene pada saat proses pembuatan kerupuk tulang ikan binggul mulai dari kesehatan pekerja,kebersihan dan lain sebagainya. Perlu untukmemperluas 


\section{DedikasiMU (Journal of Community Service)}

Volume 1, Nomor 1, Desember 2019

daerah pemasaran produk agardapat menambah jumlah produksi, dan perluuntuk meningkatkan aspek gizi dari kerupuktulang binggul agar lebih diminati dengan keunggulangizinya

\section{DAFTAR PUSTAKA}

Darseno.2010. Budi Daya dan Bisnis Lele. Jakarta Selatan: PT. AgroMedia Pustaka. Ramdany, G., I. Kusumaningrum, dan B.F. Pamungkas. 2014. Karakteristik Kimiawi Kerupuk Tulang Ikan Belida (Chital asp.). Jurnal Ilmu perikanan Tropis Vol. 19, No. 2, April 2014, hal. 68

Sukendar, A. Martinus,. N. Tanti. 2013. Pembuatan Sistem Otomatis Untuk Pengaturan Mekanisme Kerja Mesin Cetak Kerupuk Menggunakan Mikrokontroler ATMega. Jurnal FEMA, Volume 1, Nomor 1, Januari 2013.

Hemung, Bung-Orn. 2013. Properties of Tilapia Bone Powder and Its Calcium Bioavailability Based on Transglutaminase Assay. International Journal of Bioscience, Biochemistry and Bioinformatics, Vol. 3, No. 4, July 2013

Sugiyono.2003. Metode Penelitian Bisnis Bandung. Pusat Bahasa Depdiknas.

Sianipar, J. Parlindungan S. Hartono. 2009. Analisis Fungsi Produksi Intensifikasi

Usaha Tani Padi Di Kabupaten Manokwari. Informatika Pertanian Volume 18 No. 2, 2009.

Soeratno dan L. Arsyad.1999. Metodologi Penelitian untuk Ekonomi dan Bisnis.UPP AMP YKPN.Yogyakarta. Setyorini, A., I.K.G

Suandi., I.G.L. Sidiartha, W.B. Suryawan. 2009. Pencegahan Osteoporosis dengan Suplementasi Kalsium dan Vitamin D pada Penggunaan Kortikosteroid Jangka Panjang.

Sari Pediatri, Vol. 11, No. 1, hal 32-38. Kusnandar, F. 2010. Kimia Pangan Komponen Makro. Dian Rakyat: Jakarta.

Hadiwiyoto, S. 1993. Hasil-Hasil Olahan Susu, Daging, Ikan, Dan Telur. Liberty. Yogyakarta.Indira, R.A.L. 2010.Studi Evaluasi Implementasi Sarana dan Prasaran dalam Penyelenggaraan Makan Tenaga Kerja di Terminal Lawe-lawe Chevron Indonesia Company.Program Diploma III Hiperkes dan Keselamatan Kerja Fakultas Kedokteran Universitas Sebelas Maret Surakarta. 
DedikasiMU (Journal of Community Service)

Volume 1, Nomor 1, Desember 2019

Jacoeb, A.M., M. Hamdani, dan Nurjanah. 2008. Perubahan Komposisi Kimia dan

Vitamin Daging Udang Ronggeng (Harpiosquilla raphidea) Akibat Perebusan.

Buletin Teknologi Hasil Perikanan Vol. XI No. 2 Tahun 2008.Hal. 76

Manurung, D.M. 2009. Komposisi Kimia, Asam Lemak dan Kolestrol Udang Ronggeng (Harpiosquilla raphidea) Akibat Perebusan. SKRIPSI.Departemen Teknologi Hasil Perairan Fakultas Perikanan dan Ilmu Kelautan Institut Pertanian Bogor.

Handoyo, A. 2013.HACCP dan Penerapannya Dalam Industri Pangan. Disusun Guna Memenuhi Penugasan Individu Mata Kuliah Hygiene, Sanitasi dan Keselamatan Kerja. Fakultas Teknik Universitas Negeri Semarang 2013. Makala 